\title{
Military Expenditures and Inequality: Empirical Evidence from Global Data*
}

\author{
Hamid E Ali ${ }^{\dagger}$ and James Galbraith ${ }^{\ddagger}$ \\ The University of Texas at Austin \\ UTIP Working Paper NO. 24
}

October 10, 2003

\begin{abstract}
A substantial body of literature has uncovered a robust relationship between institutions-including unionization, political democracy and economic inequality. This paper examines the effect of military spending on inequality controlling for the size of armed forces, GDP growth, per capita income and other possible determinants. Using a panel regression with country level observations from 1987-1997, we obtained consistent estimates that there is a positive effect of military expenditure on pay inequality. Given the close relationship between pay and income this result suggests that a country's reduction in military spending could reduce income inequality.
\end{abstract}

\section{Introduction}

A substantial body of literature has uncovered relationships between inequality and economic and political institutions. Gradstein, Milanovic and Ying (2001) showed that democratization can reduce inequality. More generally, affluence has been correlated with the presence of democratic institutions ${ }^{1}$ (Lipset, Seong,

${ }^{*}$ We would like to thank the Ford Foundation for financial support. This paper's findings, interpretations and conclusions are entirely those of the authors. We thank seminar participants at the LBJ School of Public Affairs and the members of the University of Texas Inequality Project.

${ }^{\dagger}$ Hamid E Ali, Graduate student at the Lyndon B. Johnson School of Public Affairs, E-mail hali@mail.utexas.edu

¥James K. Galbraith holds the Lloyd Bentsen Jr. Chair in Government / Business Relations at the Lyndon B. Johnson School of Public Affairs and Chair of Economists Allied for Arms Reduction, E-mail galbraith@mail.utexas.edu

${ }^{1}$ The term "institution" has different meanings: in economics and sociology it often denotes the incorporation of values or norms into conventional patterns of social behavior that are sanctioned and enforced by formal and informal authority. "Institution" may be used in broader sense to denote a complex social, political and economic system which incorporates values and discharges services to the community Esman (1964). This commonly accepted 
Torres (1993) and Diamond (1992a)). Rodrik (1999) strongly suggested that democratic institutions are associated with higher wages; institutions do matter to distributive outcomes. Dinardo, Fortin, and Lemieux (1996) have shown that de-unionization is an important factor explaining the rise in wage inequality from 1979 to 1988. Labor market institutions, chiefly the relative decentralization of the wage-setting mechanism, provide a widely accepted explanation of wage inequality in the U.S. as compared with other OECD countries (Blau and Kahn, 1996).

Although much work has been done on the relationship between military spending and economic growth, we are not aware of any research that addresses inequality and military spending. A watershed study by Knight, Loazy and Villanueva (1996) extended a standard growth model and obtained consistent panel data estimates of the growth- retarding effects of military spending via its adverse impact on capital formation and resource allocation. This paper emulates Knight, Loazy and Villanueva's purpose and approach. However, we treat economic growth as a control variable rather than a dependent variable, and emphasize instead the relationship between military spending and inequality.

There are three ways by which higher military spending may increase economic inequality. First, increases in military spending could be at the expense of public spending on social programs such as health and education - which have an equalizing effect. The military as an institution, therefore, competes for scarce resources with other social entitlements and reduces the special advantages conferred by those social programs ${ }^{2}$.

Second, the taxes required to support military spending may fall disproportionately on the middle classes; if so post-tax income inequality may be increased. Third, high levels of military spending may reflect the use of violence as a means of social control, notably against trade unions and other egalitarian social forces. It is not surprising to witness that higher military spending means more societal control and a sacrifice of egalitarian values.

On the other hand, certain aspects of the military experience may cut in the other direction. The military absorbs low-skilled labor, which may raise wages for the young and unskilled. Mobilization for war may require equalizing concession to labor's interests. In general, the more equipment-intensive military expenditure, the more we expect the inequality-increasing effects to dominate; the more labor-intensive the military and home grown the military production, the more we might expect to find inequality-reduction effects in the data.

The purpose of this paper is to examine two important questions. First, to what extent does military spending affect inequality? Second, what are the factors that tend to influence or determine levels of military expenditure?

We note that the inequality and the military expenditure variables are both endogenous. The causation between them may run both ways - from military

use of the term institution is a point of departure in our inquiry into using the military expenditures and size of the armed forces as institutional parameters.

${ }^{2}$ Dreze (2000) for example, has criticized the Indian government's unwillingness to spend an additional 0.5 percent of GDP to ensure universal elementary education while it endorsed proposals for larger increases in military spending. 
expenditure to inequality and from inequality to military expenditure. Consequently, Ordinary Least Squares (OLS) estimates of the effect of military expenditures on inequality are likely to understate the magnitude of the effect. Our objective therefore, is to obtain estimates of the effect of military expenditure on inequality that are unaffected by simultaneity bias.

The paper is organized as follows: Section 2 describes our data on inequality, and the key variables such as military spending, armed forces and other control variables: GDP growth, per capita real income, and size of imports. Section 3 presents empirical methodology for the model specifications. Section 4 presents panel regression estimates of the effects of military spending on inequality, using a two-stage least squares regression. Section 5 discusses findings and draws some conclusions.

\section{Data on Inequality and the Key Variables}

This section describes the key variables: (1) inequality measures and trends, (2) indicators of military activities and (3) economic and regional variables.

\subsection{Inequality Measures and Trend}

As Galbraith and Berner (2001) have shown, the partition of pay data based on the International Standard Industrial classification (ISIC) is a useful way to compute between-group Theil $\mathrm{T}$ statistics and to construct from them long and dense measures of industrial pay inequality. The between-groups component of Theil's $\mathrm{T}$ has the following formula:

$$
\text { Theil }=\sum_{i=1}^{n} \frac{y_{i}}{y} \operatorname{LOG}\left(\frac{\frac{y_{i}}{y}}{\frac{N_{i}}{N}}\right) \quad \text { where } n \text { is the number of industry groups in }
$$

the sample, $y_{i}$ is the earnings in industry $i(i=1,2, \ldots ., n)$ and $y=$ total wage earnings. $N$ and $N_{i}$ represent total employment and employment of industry $i$ respectively. For a detailed discussion on the properties of the Theil's T one may refer to Theil (1979), Galbraith (1998), Galbraith and Berner (2001). Comprehensive data on industrial pay inequality world wide are available from the University of Texas Inequality Project (UTIP) ${ }^{3}$ with measures of Theil indexes computed for 160 countries over the period 1963-1999.

In the sample used in this paper, there is generally an increase of inequality in most countries from 1987-1997. Figure 1 shows a selected group of countries from different regions of the world. Countries in South America, Central America, Western Europe, South America, North Africa and the Middle East demonstrate a consistent upsurge of inequality from 1987-1997. In East Asian countries, Korea, Malaysia and Taiwan show declining inequality in the 1990s, while the Philippines show an increase.

\footnotetext{
${ }^{3}$ For most recent data on Theil index refers to UTIP web-site at http://utip.gov.utexas.edu.
} 


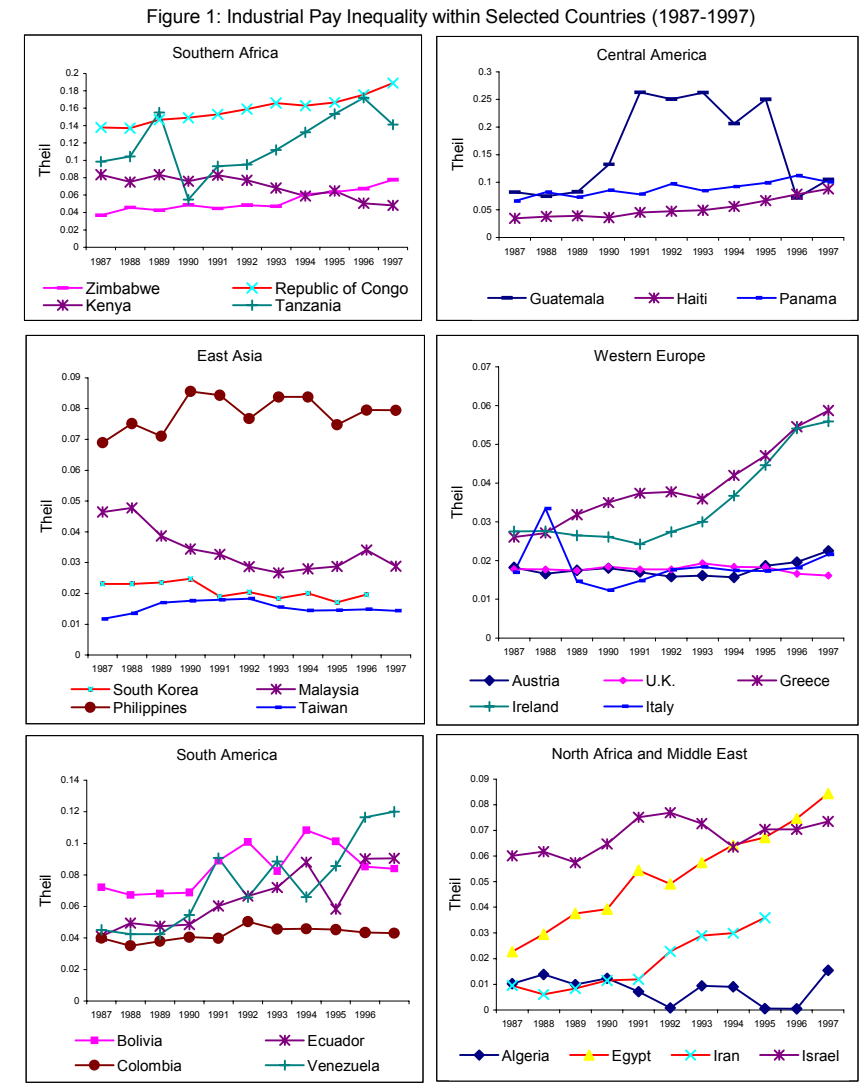

Figure 1: Industrial Pay Inequality within Selected Countries (1987-1997) 


\subsection{Indicators of Military Activities}

The U.S. Arms Control and Disarmament Agency (1998) reports that world military expenditures in the decade from 1987 to 1997 were an average of $\$ 237$ dollars per capita. By comparison, some countries in Africa have an average per capita income of $\$ 250$ dollars or less. Military expenditures in poor countries are often high relative to income and also to military need. Collier and Hoeffler (2002) for example, found that during a long period of military government in Nigeria, the navy accumulated more admirals than it had ships. This high expenditure on admirals reflects the preferences of the naval officers in the government, rather than the operational needs of the navy. Alternatively pressure from interest groups can sway policymakers to extract greater shares from government budgets for military purposes. Tanzi (1998) estimated that bribes account on average as much as 15 percent of the total spending on weapon acquisition. Corruption in campaign financing may also tend to increase public spending on the military and arms trade (Pieth, 1999).

To understand the impact of military expenditure on economic inequality, we will introduce the two most important indicators of military institutions: per capita military spending (MILEN) and size of the armed forces (ARMF).

\subsubsection{Per Capita Military Spending}

Data on aggregated military spending are provided by the U.S. Arms Control and Disarmament Agency (ACDA). Table 1 shows that in most regions of the world, military expenditures on decline after the end of the Cold War; how-

ever, the regions in East Asia, South Asia and Central Africa show increases in military expenditures.

\subsubsection{The Size of Armed Forces}

The military remains a major employer and provider of jobs and this function also has an economic impact. We therefore introduce the size of armed forces to capture the full impact of military activity on inequality. Our hypothesis is that as the size of the armed forces increases, other things equal, inequality decreases. Table 2 shows the size of armed forces on the decline in most regions of the world except for South Asia and southen African countries. Hence employment in the military is on the decline following the end of the Cold War.

\subsection{The Economic and Regional Variables}

\subsubsection{GDP growth and Per Capita Income}

It is conventional in inequality models to incorporate GDP growth (GDPG) and per capita income (RGDP1) into the analysis of income distribution. The 


\begin{tabular}{lccc|cc}
\hline & \multicolumn{3}{c|}{ Military Expenditure } & \multicolumn{2}{c}{ Growth Rate } \\
& 1987 & 1993 & 1997 & 1993 & 1997 \\
\hline \hline World & 1360 & 885 & 842 & -34.9 & -38.1 \\
$\quad$ Developed & 1120 & 688 & 610 & -38.6 & -45.5 \\
$\quad$ Developing & 234 & 197 & 232 & -15.8 & -0.9 \\
Region & & & & & \\
North America & 389 & 334 & 288 & -14.1 & -26.0 \\
Western Europe & 218 & 198 & 186 & -9.2 & -14.7 \\
East Asia & 121 & 145 & 174 & 19.8 & 43.8 \\
Eastern Europe & 472 & 88 & 65 & -81.4 & -86.2 \\
Middle East & 92 & 55.1 & 52.4 & -40.1 & -43.0 \\
South America & 22.1 & 21.5 & 28.7 & -2.7 & 29.9 \\
South Asia & 11.8 & 12.7 & 16.3 & 7.6 & 38.1 \\
Central America & 3.1 & 1.6 & 1.7 & -48.4 & -45.2 \\
Southern Africa & 7.1 & 5.2 & 5.1 & -26.8 & -28.2 \\
North Africa & 5.8 & 4.3 & 5.5 & -25.9 & -5.2 \\
Central Africa & 3.5 & 4.9 & 4.3 & 40.0 & 22.9 \\
Central Asia & -- & 5.4 & 4.4 & -- & \\
Europe, all & 691 & 286 & 251 & -58.6 & -63.7 \\
Africa, all & 16.4 & 14.4 & 14.9 & -12.2 & -9.1 \\
\hline \hline
\end{tabular}

Table 1: World Military Expenditures ( in constant 1987 dollars) 


\begin{tabular}{lccc|cc}
\hline & \multicolumn{3}{c|}{$\begin{array}{c}\text { Armed Forces } \\
\text { (in millions) }\end{array}$} & \multicolumn{2}{c}{ Growth Rate } \\
& 1987 & 1993 & 1997 & 1993 & 1997 \\
\hline \hline World & 28.3 & 24 & 22.3 & -15.2 & -21.2 \\
$\quad$ Developed & 12.00 & 8.2 & 7.18 & -31.7 & -40.2 \\
$\quad$ Developing & 16.4 & 15.8 & 15.1 & -03.7 & -7.9 \\
Region & & & & & \\
North America & 2.51 & 2.07 & 1.84 & -17.5 & -26.7 \\
Western Europe & 3.87 & 3.21 & 3.02 & -17.1 & -22.0 \\
East Asia & 8.05 & 7.75 & 6.96 & -3.7 & -13.5 \\
Eastern Europe & 5.65 & 3.21 & 2.8 & -43.2 & -50.4 \\
Middle East & 2.70 & 2.45 & 2.47 & -09.3 & -8.5 \\
South America & 1.19 & 0.91 & 0.94 & -23.3 & -21.2 \\
South Asia & 1.95 & 2.15 & 2.18 & 10.3 & 11.8 \\
Central America & 0.54 & 0.36 & 0.17 & -34.7 & -68.0 \\
Southern Africa & 0.44 & 0.45 & 0.36 & 03.7 & -18.0 \\
North Africa & 0.49 & 0.44 & 0.42 & -11.6 & -15.0 \\
Central Africa & 0.83 & 0.69 & 0.71 & -15.6 & -14.1 \\
Central Asia & -- & 0.19 & 0.29 & -- & -- \\
Europe, all & 9.52 & 6.42 & 5.82 & -32.6 & -38.9 \\
Africa, all & 1.76 & 1.59 & 1.49 & -09.7 & -15.3 \\
\hline \hline
\end{tabular}

Table 2: World Armed Forces 
theoretical argument is based on the Kuznets hypothesis and a voluminous literature on inequality (Galbraith (1999), Loury (1981), Champernowne, (1953)). In general, we anticipate that as per capita income increases inequality should fall; most countries are on a downward sloping portion of the Kuznets curve. The literature gives a mixed view of the relationship between the economic growth rate and inequality; ours is simply that in booms jobs are plentiful and pay inequalities tend to decline. Data on income level and GDP growth are obtained from Penn World Tables (1998).

\subsubsection{Imports}

Countries have different measures of protection against the import of goods and services. In general, we expect countries with high barriers and low import shares to be relatively more equal - the function of protection is, after all, to protect. The data on the volume of imports is obtained from ACDA (1998).

\subsubsection{Regional Variables}

Regional dynamics such as excessive military spending by neighbors or wars in the region can affect inequality. On the other hand dividends of peace and prosperity can be shared among neighboring countries, which can reduce levels of inequality. Controlling for regional variation therefore is important. Our study includes 160 countries that are divided into eleven regions. We introduce control variables for North Africa, Central Africa, South Africa, North America, Central America, South America, East Asia, South Asia, Middle East, Western Europe and Eastern Europe as regional dummies (REG)

\section{Model and Empirical Methodology}

This section describes the econometric model. We use a panel regression, on country level observations, extending from 1987-1997. We initially discuss the determinants of inequality followed by a specification for the demand for military expenditures.

\subsection{Regression Model}

We first, use a single equation to investigate the impact of military spending on inequality. Our starting point is the following model for pay inequality:

$$
\begin{aligned}
\text { THEIL }_{i t}= & \beta_{1}+\beta_{2} \text { MILEN }_{i t}+\beta_{3} G D P G_{i t}+\beta_{4} R G D P 1_{i t}+ \\
& \beta_{5} T I M N_{i t}+\beta_{6} A R M F_{i t}+\beta_{7} G * T I M N_{i t}+ \\
& \beta_{8} R G D P W G_{i t}+\sum \beta_{k} R E G_{i t}+\nu_{i}+\varepsilon_{i t}
\end{aligned}
$$

For a description of the variables in equation (1) refer to the appendix. Equation (1) regresses inequality (THEIL) on explanatory variables: military 
expenditure (MILEN), GDP growth rate (GDPG), the share of imports in GNP (TIMN), the size of armed forces (ARMF), regional dummies and interactions between GDPG and TIMN (G*TIMN) and GDP growth with RGDP (RGDPWG). $v$ is a country specific factor such as geopolitical, cultural and other attributes. $\varepsilon$ represents a white noise error term.

Regression results are valid as long as there is one endogenous variable. What if we have more than one endogenous variable? What if, in other words, pay inequality and military spending are determined simultaneously? In such cases we need to deal with the issue of endogeneity and to find ways to obtain unbiased and consistent estimates.

\subsection{Simultaneous Regression Model}

Unequal societies may choose higher military spending because increased military spending can bring stability, for example through suppression of dissidents. On the other hand, the opportunity cost of higher military spending can lead to more inequality. If estimates using a single equation model are biased and inconsistent, then it becomes necessary to estimate the determinants of military spending with instruments that may be used to treat the simultaneity bias. This is the standard method of simultaneous equations models.

We postulate two endogenous variables: THEIL and MILEN, and several predetermined variables (instruments), to be described below. The process of implementing 2SLS is as follows: in the first-stage regression, we obtain the "estimated THEIL" and the "estimated MILEN". In the second stage we replace

the MILEN by the "estimated MILEN" in equation (1) to obtain coefficient $\hat{\beta}_{i}$ for equation (1). In order to obtain unbiased estimates for original postulated coefficients $\alpha_{i}$ in equation (2) see below we need to replace the THEIL by the "estimated THEIL" as an instrumental variable in equation (2).

\subsubsection{Military Expenditure Equation}

Our model defines per capita military expenditure as a function of levels of inequality (THEIL), per capita income (RGDP1), share of arms imports in total imports (AITI), size of the armed forces (ARMF), and level of engagement in the arms trade (ARMTR), and size of the population. $v$ represents the country effects and $\eta$ represents the error term. The military expenditures equation is:

$$
\begin{aligned}
\operatorname{MILEN}_{i t}= & \alpha_{1}+\alpha_{2} \text { THEIL } L_{i t}+\alpha_{3} R G D P 1_{i t}+\alpha_{4} A I T I_{i t}+ \\
& \alpha_{5} A R M F_{i t}+\alpha_{6} A R M T R_{i t}+\alpha_{7} P O P_{i t}+V_{i}+\eta_{i t}
\end{aligned}
$$

\subsubsection{Determinants of Military Expenditures}

It should be recognized that there are no unique models for estimating determinants of military expenditure, for discussion see Smith (1977). From public 
choice theory, military spending is a type of public good but imperfect information makes it difficult for economic agents to assess the true value of military spending. Recent writings on the demand for military expenditures emphasize social choice theory: resources committed for public and private consumption and investment is determined by a benevolent leadership whose objective is to maximize social welfare (Hewitt, 1992).

The public-choice-based discussion of military expenditure obscures the politics and competing alternatives that are ruled out due to pressures from interest groups. Military issues involve secrecy; sometimes threats are manufactured to justify military spending. These concerns make it difficult to justify using models based on social choice theory.

\section{Inequality (THEIL)}

We believe the level of inequality has an impact on the demand for military spending. Unequal societies encounter a greater social and political unrest that require an increase in military spending to maintain social stability, especially in developing countries. As inequality increases, military spending therefore should be expected to rise.

\section{Per Capita Income (RGDP1)}

In general, the higher the per capita income, the higher the military spending; the military needs are normal goods.

\section{Armed Forces (ARMF)}

The size of armed forces is of course an important determinant of military expenditures. Once military institution commits to a specific size of armed forces, they maintain forces in most cases and military expenditure is therefore is an endogenous consequence of free structure. As the size of armed forces increases military spending should increase.

\section{Arms Imports (AITI)}

Arms imports are a component of military spending, but they may be funded off-budget, by credit and by grant aid. This can create a substitution effect so that a government will spend less on the military overall, from budget resources than would otherwise be the case. Arms importers also face a foreign exchange constraint, and may have less powerful local lobbies than arms producers. For this reason, we expect that countries which import a larger share of their armaments will spend less overall, other things equal, than countries which produce armaments at home.

\section{Arms Trading (ARMTR)}

The armaments trades may be a separate reason for high military spending, and therefore a useful instrument for predicting MILEN. We created the index (ARMTR) to distinguish countries that both import and export arms from countries that only import them. This measure is created by the interaction of 


\begin{tabular}{lccc}
\hline \multicolumn{1}{c}{ Variable } & N & Mean & Std. Dev \\
\hline \hline Theil (Theil Index) & 1047 & 0.08156 & 0.00348 \\
MILEN (Per capita Military Expenditure ) & 1559 & 237.343 & 18.0600 \\
GDPG (GDP Growth Rate) & 1344 & 3.2840 & 0.18454 \\
AIMT (Arms Imports as \% Total Imports) & 1551 & 5.4608 & 7.16254 \\
ARMF (Armed Forces per 1000 People) & 1548 & 7.16254 & 0.19553 \\
TIMN (Total Imports as \% of GNP) & 1548 & 30.4793 & 0.5566 \\
RGDP1 (Real GDP per Capita) & 1302 & 2083.88 & 6202.19 \\
\hline \hline
\end{tabular}

Table 3: Simple Statistics on Military Expenditures and Pay Inequality

a dummy variable that defines whether a country is an arms exporter with the variable AITI.

\section{Estimation Results}

Table 3 presents descriptive statistics for pay inequality. Single equation estimates for equation (1) are reported in Table 4; given that they are biased and inconsistent we will not discuss them. Equation (1) and (2) are estimated using two-stage least squares. The regression results explaining variation in inequality in equation (1) are reported in Table 5 . Table 5 shows that the estimates generated from the system of equations are robust. In regression (1)-(3) the variables -GDPG, RGDP1, G*TIMN, RGDPWG and REG are significant at the 0.05 significant level.

The results show a positive and significant - though of course small-relationship between military spending and inequality. Consistent with previous work, the rate of GDP growth and level of per capita income show evidence of a negative relationship with inequality. This result supports our hypothesis and much evidence from other work. The interaction between GDP growth and the level of income (RGDPWG) has a negative impact on inequality. If a country satisfies the condition of high income and high growth, inequality should fall because people are getting plenty of jobs with high pay.

The interaction term between the size of imports and GDP growth (G*TIMN) is also significant at the 0.05 significance level. Importing capital goods; such as machines and equipment promotes growth, while importing non-capital goods such as luxury items is detrimental to growth.

Estimates of the size of armed forces appear to have significant and negative effects on inequality. The regional dummy variables are statistically significant except for North Africa and Eastern Europe. The regional regressors are able to account for some variations in inequality. Overall, we find that the inequality model in Table (5) column (1) - (3) provide the best fit to the data, with an $\mathrm{R}$-squared ranging from 68 percent to 75 percent. 


\begin{tabular}{lcccccc}
\hline Re gressions & $(1)$ & $t-$ value & $(2)$ & $t-$ value & $(3)$ & $t-$ value \\
\hline \hline Intercept & 0.197 & 7.27 & 0.196 & 7.25 & 0.203 & 7.56 \\
MILEN & -.000007 & 0.52 & -.000001 & 0.08 & 0.000005 & 0.42 \\
GDPG & $-.001 * * *$ & 4.70 & $-.002 * * *$ & -5.13 & $-.002 * * *$ & 6.6 \\
RGDP 1 & -.000002 & 2.58 & -.000001 & 1.63 & -.000002 & 2.61 \\
& $* * *$ & & $*$ & & $* * *$ & \\
TIMN & -.019 & 1.26 & 0.027 & 1.26 & $0.031 *$ & 1.47 \\
ARMF & -.0003 & 0.96 & -.0004 & 1.31 & -.00049 & 1.39 \\
G*TIMN & ---- & -- & -.0000003 & 2.28 & -.000003 & 2.52 \\
& & & $* *$ & & $* * *$ & \\
RGDPWG & ---- & -- & ---- & -- & -.00000002 & 4.08 \\
& & & & & $* * *$ & \\
NAFRICA & -0.001 & 0.01 & -.002 & 0.04 & .002 & 0.03 \\
CAFRICA & $-.158 * * *$ & 5.35 & $-.156 * * *$ & 5.35 & $-.161 * * *$ & 5.61 \\
SAFRICA & $-.116 * * *$ & 4.13 & $-.123 * * *$ & 4.32 & $-.127 * * *$ & 5.51 \\
CAMERICA & $-.158 * * *$ & 5.71 & $-.165 * * *$ & 5.92 & $-.168 * * *$ & 6.08 \\
SAMERICA & $-.107 * * *$ & 3.78 & $-.116 * * *$ & 4.03 & $-.120 * * *$ & 4.23 \\
MEAST & $-.121 * * *$ & 3.92 & $-.126 * * *$ & 4.07 & $-.129 * * *$ & 4.23 \\
EASIA & $-.129 * * *$ & 4.85 & $-.139 * * *$ & 5.13 & $-.145 * * *$ & 5.42 \\
SASIA & $-.125 * * *$ & 4.41 & $-.137 * * *$ & 4.78 & $-.139 * * *$ & 4.93 \\
EUROPE & -.012 & 0.55 & -.012 & 0.53 & -.012 & 0.54 \\
WUROPE & $-.124 * * *$ & 4.65 & $-.135 * * *$ & 4.93 & -.138 & 5.12 \\
F - statistics & 17.29 & -- & 17.88 & -- & $18.28 * * *$ & -- \\
$R-$ squared & 0.73 & -- & 0.73 & -- & 0.73 & -- \\
Number & 776 & -- & 776 & -- & 776 & -- \\
\hline \hline
\end{tabular}

$* * *, * *, *$ indicate significance at the 1,5, and 10 percent level respectively.

Table 4: Single Equation One-way Fixed Effects: Dependent Variable THEIL 


\begin{tabular}{lcccccc}
\hline Re gressions & $(1)$ & $t-$ value & $(2)$ & $t-$ value & $(3)$ & $t-$ value \\
\hline \hline Intercept & 0.200 & 7.11 & 0.213 & 6.85 & 0.21924 & 8.75 \\
MILEN & $0.0002 * * *$ & 2.81 & $0.0003 * * *$ & 3.16 & $0.0001 * *$ & 1.81 \\
GDPG & $-.001 * * *$ & 3.35 & $-.002 * * *$ & 4.32 & $-.003 * * *$ & 7.91 \\
RGDP 1 & -.000001 & 3.68 & -.000001 & 3.43 & -.0000003 & 3.04 \\
& $* * *$ & & $* * *$ & & $* * *$ & \\
TIMN & $-.037 * *$ & 2.10 & $0.078 * * *$ & 2.50 & $0.056 * *$ & 2.35 \\
ARMF & $-.001 * *$ & 2.37 & $-.002 * * *$ & 2.86 & $-0.001 * * *$ & 2.08 \\
G*TIMN & ---- & -- & -.000001 & 3.96 & -.000001 & 3.74 \\
& & & $* * *$ & & $* * *$ & \\
RGDPWG & ---- & -- & ---- & -- & -.00000002 & 4.99 \\
& & & & & $* * *$ & \\
NAFRICA & -.012 & 0.20 & -.017 & 0.26 & -.00023 & 0.00 \\
CAFRICA & $-.154 * * *$ & 4.95 & $-.189 * * *$ & 5.52 & $-.193 * * *$ & 6.98 \\
SAFRICA & $-.104 * * *$ & 3.47 & $-.136 * * *$ & 4.14 & $-.143 * * *$ & 5.38 \\
CAMERICA & $-.127 * * *$ & 4.11 & $-.162 * * *$ & 4.94 & $-.186 * * *$ & 7.23 \\
SAMERICA & $-.091 * * *$ & 2.97 & $-.125 * * *$ & 3.83 & $-.137 * * *$ & 5.19 \\
MEAST & $-.097 * * *$ & 2.88 & $-.121 * * *$ & 3.39 & $-.142 * * *$ & 5.04 \\
EASIA & $-.137 * * *$ & 4.84 & $-.178 * * *$ & 5.64 & $-.168 * * *$ & 6.72 \\
SASIA & $-.104 * * *$ & 3.40 & $-.146 * * *$ & 4.44 & $-.157 * * *$ & 5.95 \\
EUROPE & -.017 & 0.74 & -.017 & 0.69 & -.013 & 0.64 \\
WUROPE & $-.137 * * *$ & 4.77 & $-.184 * * *$ & 5.62 & $-.162 * * *$ & 6.39 \\
F - statistics & 13.46 & -- & 11.86 & -- & 18.18 & -- \\
$R-$ squared & 0.68 & -- & 0.66 & -- & 0.75 & -- \\
Observation & 774 & -- & 712 & -- & 712 & -- \\
\hline \hline * * * *** $*$ indicate significance at the 1,5, and 10 percent level respectively. &
\end{tabular}

Table 5: Simultaneous Equation One-way Fixed Effects: Dependent Variable Theil 


\begin{tabular}{lcccccc}
\hline Equations & $(1)$ & $t-$ value & $(2)$ & $t-$ value & $(3)$ & $t-$ value \\
\hline \hline Intercept & -104.74 & 4.76 & -100.67 & 4.58 & -113.03 & 5.34 \\
THEIL & 564.76 & 2.33 & 365.57 & 1.65 & 119.12 & .59 \\
RGDP1 & 0.0344 & 30.89 & 0.0348 & 30.45 & 0.0334 & 30.36 \\
AITI & -3.6515 & 6.06 & -4.4017 & 6.93 & -4.135 & 6.76 \\
ARMF & 5.5346 & 6.74 & 5.6455 & 6.74 & 6.12 & 7.58 \\
ARMTR & ---- & -- & 2.417 & 2.98 & 1.905 & 2.44 \\
POP & ---- & -- & ---- & -- & 1.1814 & 6.77 \\
F- statistics & 139.31 & -- & 139.87 & -- & 150.17 & -- \\
R- squared & 0.95 & -- & 0.95 & -- & 0.96 & -- \\
Observation & 774 & -- & 712 & -- & 712 & -- \\
\hline \hline
\end{tabular}

Table 6: Simultaneous Equation Estimation the Dependent variable is Military Expenditure

\subsection{The Military Expenditures Estimates}

The regression results from equation (2) are estimates of the demand for military expenditures. Table 6 presents evidence on the empirical relationship between military expenditures and THEIL, level of income, size of arms imports, and intensity of arms trade.

\subsubsection{Military Variables}

The significance of the coefficients on arms imports, intensity of arms trade and the size of armed forces supports the main hypothesis of the model of determinants of military expenditures. Table 6 indicates that there is clear evidence of a positive link between the intensity of the arms trade and military expenditures. The size of arms imports is also found to be at 0.05 level of significance and the coefficient is negative as expected.

\subsubsection{Economic Variables}

The per capita income variable in Table 6 shows that for every dollar increase in income, $\$ 0.03$ dollars are spent on the military after controlling for the other factors.

\subsubsection{Inequality Variable}

Not surprisingly, more unequal societies spend larger amounts on military spending. The Theil variable has a positive and significant relationship with military expenditure. 


\section{Conclusion}

This study has attempted to examine the relationship between military spending and inequality. Our hypothesis, was that as per capita military expenditure increases, inequality increases, controlling for the size of armed forces, and for regional and economic variables. Our findings lend support to the hypothesis that expenditure on militarization drains resources from public spending on agricultural research, development of infrastructure and other social programs that may lend to promote development and reduce economic inequality.

Also we developed a simple model of determinants of military spending as a function of economic, and institutional variables, and the level of inequality. We obtain estimates that are robust, and that suggest a causal relation between the level of inequality and military expenditures. However, the issue of the causation remains worthy of further research. 


\section{A Appendix}

\begin{tabular}{ll}
\hline \multicolumn{1}{c}{ Variable } & \multicolumn{1}{c}{ Description } \\
\hline \hline Theil (Theil Index) & \multicolumn{1}{c}{ Theil Index } \\
$M I L E N$ & Per capita Military Expenditure in (1997 dollars) \\
GDPG & GDP Growth Rate \\
$A I M T$ & Arms Imports as \% Total Imports \\
$A R M F$ & Armed Forces per 1000 People \\
$T I M N$ & Total Imports as \% of GNP \\
$R G D P 1$ & Real GDP per Capita (1997 price) \\
$G * T I M N$ & Interaction term of GDP growth and TIMN \\
RGDPWG & Interaction term of GDP growth and RGDP1 \\
ARMEX & Interaction term of arms export and Arms import \\
NAFRICA & North Africa \\
$C A F R I C A$ & Central Africa \\
NAFRICA & North America \\
$C A M E R I C A$ & Central America \\
SAMERICA & South America \\
$E A S I A$ & East Asia \\
$M E A S T$ & Middle East \\
SASIA & South Asia \\
$W E U R O P E$ & Western Europe \\
EUROPE & East Europe \\
\hline \hline
\end{tabular}

Table 7: Description of Variables and Data Unit 


\section{References}

[1] Blau, Francine D., and Lawrence M. Kahn, "International Differences in Male Wage Inequality: Institutions versus Market Forces," Journal of Political Economy, CIV(August 1996), 791-837.

[2] Champernowne, David "A Model of Income Distribution," Economic Journal 63 (1953), 318-51.

[3] Diamond, Larry "Economic Development and Democracy Reconsidered," in G. Marks and L. Diamond, ed., Reexamining Democracy :Essays in Honor of Seymour Martin Lipset 1992a ( Newbury, Park, CA: Sage).

[4] Dinardo, John, Nicole M. Fortin, and Thomas Lemieux, "Labor Market Institutions and the Distribution of wages, 1973-1992: A semi-Parametric Approach," Econometrica, LXIV(September 1996), 1001-1044.

[5] Collier, Anke Hoeffler "Military Expenditure: Threats, Aid and Arms Races," Working paper, World Bank (2002).

[6] Esman, Milton "Institutional Building in National Development," in Grove Hambidge, Dynamics of Development and International development Reader (New York: Fredrick Praeger, 1964).

[7] Galbraith, James K. " Created Unequal: The Crisis in American Pay," Free Press (1998).

[8] Galbraith, James K. and Berner, M., " Inequality and Industrial Change: A Global View," Cambridge: Cambridge University Press (2000).

[9] Gradestein, Milanovic and Yvonne Ying "Democracy and Income Inequality: An Empirical Analysis," World Bank, Washington, DC, December, 2001.

[10] Gupta, De Mello and Raju Sharan "Corruption and Military Spending," Working paper International Monetary Fund (2000).

[11] Hewitt, Daniel "Military Expenditures Worldwide: Determinants and Trends, 1972-1988," Journal of Public Policy Vol 12(1992) 105-52.

[12] Dreze, Jean "Militarism, Development and Democracy," Economic and Political Weekly (April, 2000) 1171-1183.

[13] louray, Glenn "Intergenerational Transfers and the Distribution of Earnings," Econometrica 49 (1981), 843-67.

[14] Lipset, Seymour Martin, Kyoung-Rung Seong and John Chareles Torres "A Comparative Analysis of Social Requisite of Democracy," International Social Journal 45 (1993), 155-75. 

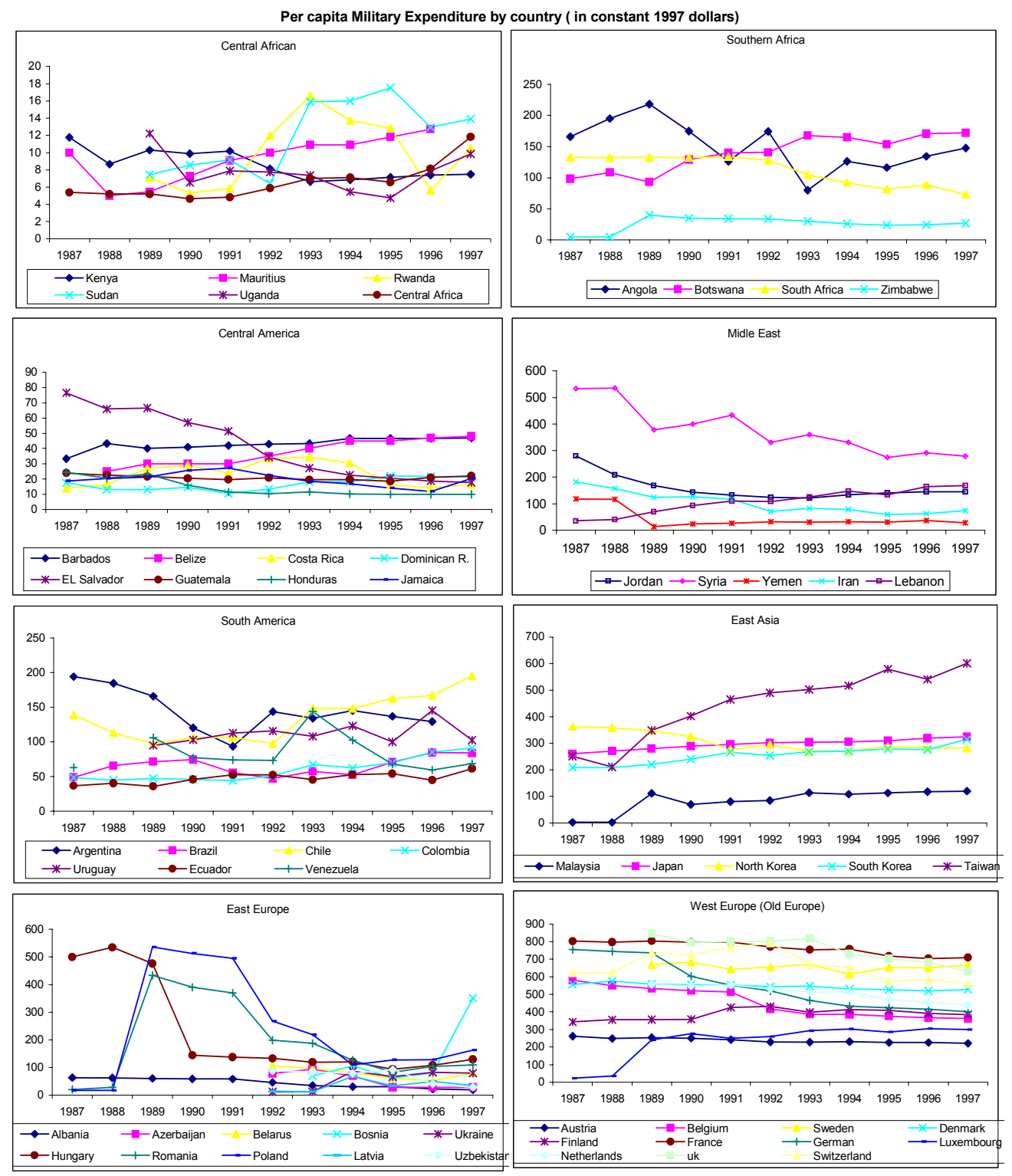

Figure 2: Percapita Military Expenditure by country (in constant 1997 dollars) 
[15] Knight, Loazy and Delano Villanueva "The Peace Dividend: Military Expending Cuts and Economic Growth," Staff Papers, International Monetary Fund, Vol.43(March,1996).

[16] Tanzi, Vito "Corruption Around the World: Causes, Consequencies, Scope and Cures," Staff Papers, International Monetary Fund, Vol. 45(December 1998) 559-594.

[17] Pieth, Mark Chairman of the OECD Working Group for Bribery, Manila (October, 1999).

[18] Smith, R.P. "Military Expenditure and Capitalism," Cambridge Journal of Economics, vol 1(1977).

[19] United Nation Industrial Development Organization (UNIDO), "Industrial Statistics Data Base," (2000 ).

[20] University of Texas Inequality Project (UTIP), 2000 Web-site http://utip:gov.utexas.edu

[21] US Arms Control and Disarmament Agency (ACDA), 1998. 